Вісник Дніпропетровського університету. Біологія. Медицина. - 2010. - Вип. 1, т. 2. - С. 38 -42. Visnyk of Dnipropetrovsk University. Biology. Medicine. - 2010. - Vol. 1, N 2. - P. 38-42.

\title{
УДК 59.089
}

М. О. Кісякова, Г. П. Гаврилюк, Т. Н. Полішко, В. М. Моісеєнко, А. І. Вінніков

Дніпропетровський національний університет ім. Олеся Гончара

\section{ПЕРСПЕКТИВИ ВИКОРИСТАННЯ ЛІПОСОМ ДЛЯ СТВОРЕННЯ НОВИХ ФОРМ ЛІКУВАЛЬНО-ПРОФІЛАКТИЧНИХ ПРЕПАРАТІВ}

\begin{abstract}
Наведено дані про структуру та фізико-хімічні властивості фосфоліпідних везикул (ліпосом) ефективних природних носіїв лікарських речовин. Описані різновиди ліпосом, методи їх отримання, механізми проникнення в клітини організму та функціональні особливості ліпосомальних препаратів. Наведено дані щодо отримання ліпосом із безклітинним гомогенатом лактобактерій, а також методи контролю структури ліпосом.
\end{abstract}

М. А. Кисякова, А. Ф. Гаврилюк, Т. Н. Полишко, В. Н. Моисеенко, А. И. Винников

Днепропетровский национальный университет им. Олеся Гончара

\section{ПЕРСПЕКТИВЫ ИСПОЛЬЗОВАНИЯ ЛИПОСОМ ДЛЯ СОЗДАНИЯ НОВЫХ ФОРМ ЛЕЧЕБНО-ПРОФИЛАКТИЧЕСКИХ ПРЕПАРАТОВ}

\begin{abstract}
Представлены данные о структуре и физико-химических свойствах фосфолипидных везикул (липосом) - эффективных природных носителей лекарственных веществ. Описаны разновидности липосом, методы их получения, механизмы проникновения в клетки организма и функциональные особенности липосомальных препаратов. Приведены данные по получению липосом с бесклеточным гомогенатом лактобактерий, а также методы контроля структуры липосом.
\end{abstract}

M. A. Kisjakova, A. F. Gavrylyuk, T. N. Polishko, V. M. Moiseenko, A. I. Vinnikov

Oles' Gonchar Dnipropetrovsk National University

\section{PROSPECTS OF LIPOSOMES USING FOR CREATING OF NEW FORMS OF THE MEDICINAL AND PREVENTIVE PREPARATIONS}

Information on the structure, physical and chemical characteristics of the phospholipid vesicles (liposomes) - the effective natural drug delivery system is presented. Types of liposomes, procedures of its productions, penetration mechanisms into cells and functional features of liposomal drugs are described. Data on production of liposomes with lactobacilli acellular homogenates and the methods of the liposomes structure control asre demonstrated.

Перспективи впровадження лікарських засобів у ліпосомальній формі

Застосування нових ефективних лікарських засобів з мінімальною побічною дією для лікування захворювань різної етіологічної природи різних органів і систем актуальний напрям сучасної медицини. Більшість лікарських препаратів, що вживаються в традиційних формах, досить обмежено проникають через клітинні мембрани та після надходження в організм піддаються істотній біотрансформації, унаслідок чого втрачають свою фармакологічну активність. Саме тому сьогодні при розробці нових лікарських засобів увага багатьох авторів зосереджена на дослідженні можливості збільшення здатності препаратів легко проникати через бар'єри біомембран у клітини-

(C) М. О. Кісякова, Г. П. Гаврилюк, Т. Н. Полішко, В. М. Моісеєнко, А. І. Вінніков, 2010 38 
мішені, а також пролонгуванні їх дії. Перспективне у цьому напрямку використання як транспортного засобу ліпідних везикул, що отримали назву «ліпосоми» $[8 ; 13 ; 18 ; 20]$.

\section{Загальні уявлення про будову та використання ліпосом}

Ліпосоми - штучні сферичні частки, які складаються з бішарів фосфоліпідів, що оточують центральну водну порожнину та самоорганізуються при фазовому переході завдяки амфіфільній структурі ліпіду [1;9;13].

Ліпосоми вперше отримано та описано у 1964 році американським ученим Алексом Бенгхемом, який працював над вивченням властивостей фосфоліпідів - основних компонентів клітинних мембран [3; 4]. Ліпосоми швидко стали предметом численних досліджень, спочатку як моделі клітинних мембран, а потім уже як носії ліків [1]. Пік розвитку досліджень ліпосомних структур спостерігався у 1980-х роках, коли було запатентовано основні методи отримання різноманітних фосфоліпідних везикул [4].

Зараз ліпосоми - широко розповсюджений комерційний продукт. За даними реферативного збірника «Винаходи країн світу», опубліковано понад 670 патентних документів, що є результатом вивчення ліпосом. У цій галузі лідерами є Японія, США, Німеччина, Франція, Великобританія та Швейцарія.

За оцінками американських фахівців, до 2000 року сума продажів ліпосом як засобів траспортування становила 2-5 млрд. доларів США, або 20-25 \% світового ринку засобів доставки лікарських препаратів [10].

Кількість мембранних шарів у ліпосомі може бути різною, що впливає на ії розміри та будову. Ліпосоми бувають одношарові розміром 25-50 нм (МОВ - малі одношарові везикули, SUV - small unilamellar vesicles) та понад 50 нм (BOB - великі одношарові везикули, LUV - large unilamellar vesicles); багатошарові (БШВ - багатошарові везикули, MLV - multilamellar vesicles), розміром 100 нм - 3 мкм [4; 11; 18]. Найпоширеніші ліпосомальні засоби з препаратом гідрофільної природи, що міститься у водній порожнині ліпосоми. Це пояснюється відносною простотою створення таких ліпосомальних систем за умови якщо терапевтична концентрація лікарської субстанції не впливає негативно на стабільність самої ліпосоми. До ліпосомних препаратів другої генерації належать ліпосоми, що містять водонерозчинні (суспендовані) та жиророзчинні лікарські речовини, які включаються безпосередньо у фосфоліпідний бішар. Технологія їх отримання значно складніша, проте такі препарати мають цінні фармакологічні властивості $[1 ; 4 ; 19]$.

Перспективні для використання стійкі до впливу фізико-хімічних факторів ліпосоми. Важливим кроком стала модифікація поверхні ліпосом полімерами 3 гнучким гідрофільним ланцюгом, найчастіше поліетиленгліколем, які отримали назву «стерично стабілізовані», або «ліпосоми-невидимки» - stealth liposomes. Такі ліпосоми характеризуються збільшеним часом циркуляції в системі кровообігу та стабільністю, завдяки тому що не можуть «виловлюватися» клітинами ретикуло-ендотеліальної системи $[1 ; 4 ; 5 ; 17 ; 20 ; 21]$. Із метою керованого транспорту біологічно активної речовини до поверхні ліпосоми приєднують молекули, споріднені до конкретного органа чи клітини-мішені, наприклад, імуноглобуліни, лектини, глікопротеїни, ліпіди чи екстракти певних клітин і тканин. Такі ліпосоми отримали назву «автоліпосоми», «імуносоми», «протеоліпосоми», «вірусоми» тощо [2; 4; $10 ; 21]$.

Запропоновано використання ліпосом для створення штучних еритроцитів (гемосоми), транспортування генетичного матеріалу, радіоактивних і контрастних речовин $[1 ; 10 ; 11]$. 
Взаємодія ліпосом із клітинами здійснюється за кількома основними механізмами: проникнення крізь пори клітинної мембрани, адсорбція на поверхні клітин, ендо- або фагоцитоз ліпосом, злиття чи обмін фосфоліпідів із плазматичною мембраною, взаємодія з поверхневими рецепторами клітин $[1 ; 7 ; 13]$.

Механізм проникнення ліпосом у клітини залежить від їх розміру та фізичних властивостей, які залежать від хімічної природи компонентів ліпідного бішару, технології отримання ліпосом, а також від морфологічного типу клітини та наявності в ній специфічних рецепторів. Жоден механізм проникнення не виключає іншого, i, як правило, шляхи можуть поєднуватися [4; $11 ; 13]$.

Дія препарату багато в чому залежить від того, який із механізмів буде переважати. Особливості будови ліпосом і їх біологічна сумісність із клітиною, здатність утримувати у водній і жировій фазі різноманітні речовини та здатність до біодеградації в організмі характеризують їх як ефективні носії лікарських субстанцій [4; 5; 14].

Як стверджує більшість дослідників, у ліпосому може бути включено практично будь-яку сполуку. Як носії лікарських препаратів ліпосоми, безумовно, мають ряд переваг: можливість включення в них малорозчинних і токсичних речовин, біологічна сумісність із ферментними та імунними системами організму, особлива сукупність біологічних властивостей, характерних для функцій клітинної мембрани, адгезивність, стимуляція фагоцитозу, імунокорегуючий або імуносупресивний (залежно від складу ліпосом) ефекти. Крім того, доведено, що ліпосоми мають антиоксидантні властивості $[4 ; 13 ; 21]$.

Отже, ліпосомні препарати мають низку незаперечних переваг:

- захищають клітини організму від токсичної дії лікарських засобів;

- пролонгують дію введеного в організм лікарського засобу;

- захищають лікарські речовини від деградації;

- сприяють спрямованій специфічності за рахунок селективної проникності 3 крові у тканини;

- змінюють фармакокінетику лікарських препаратів, підвищуючи їх фармакологічну ефективність;

- дозволяють створювати водорозчинну форму низки лікарських субстанцій, таким чином збільшуючи їх біодоступність [4; 13].

Упродовж останніх 20 років у практиці світової фармакології інтенсивно застосовують ліпосомні препарати (близько 20 комерційних ЛСП) у різних галузях медицини - онкології, пульмонології, гастроентерології, офтальмології, кардіології тощо $[8 ; 13-16 ; 19]$.

\section{Створення ліпосом}

При створенні ліпосом найширше використовуються фосфоліпід фосфатидилхолін (стара назва якого лецитин) і холестерин, який надає щільності створюваній мембрані. Порівняно з іншими ліпідами фосфатидилхолін має вищий рівень стабільності та легко утворює стійкі везикули, $є$ природним антиоксидантом, підвищує пластичність мембран клітин [4; 13]. На даний час існує багато способів отримання ліпосом із заданими властивостями та функціями, до складу яких уходять різноманітні сполуки різного походження та природи.

Нами проведено серію експериментів 3 отримання ліпосом двома 3 найпоширеніших способів.

У першій серії експериментів використовували соєвий лецитин, який розчиняли в органічному розчиннику, перемішували на магнітній мішалці, додавали стабілізатор 
та буферний розчин. Отриману суспензію ліпосом розглядали під мікроскопом при збільшенні $\times 630$ (рис. 1).

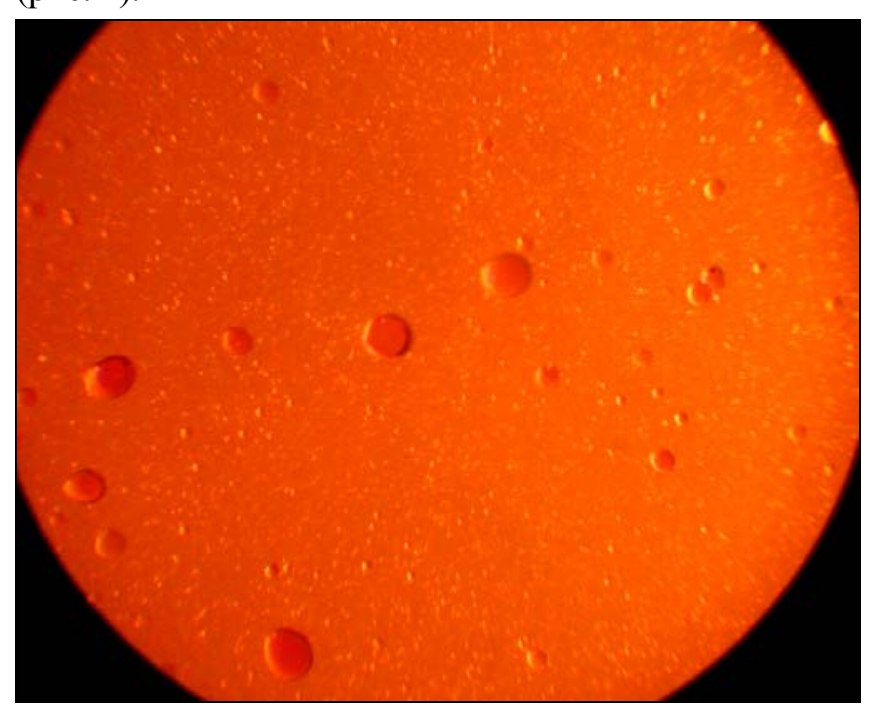

Рис. 1. Суспензія ліпосом (збільшення ×630)

У другій серії експериментів використовували соєвий лецитин, який розчиняли в органічному розчиннику, додавали стабілізатор та обробляли ультразвуком [11]. Отриману суспензію ліпосом розглядали під мікроскопом при збільшенні $\times 500$ (рис. 2). У наступній серії експериментів поставили завдання отримати тест-системи з включення безклітинного гомогенату лактобактерій у ліпосоми. Для цього суспензію лактобактерій забарвлювали флуоресцентним барвником акридиновим оранжевим, обробляли ультразвуком і центрифугували. Після цього отриманий таким чином безклітинний гомогенат поміщали в ліпосоми останнім із вищенаведених способів (рис. 3).

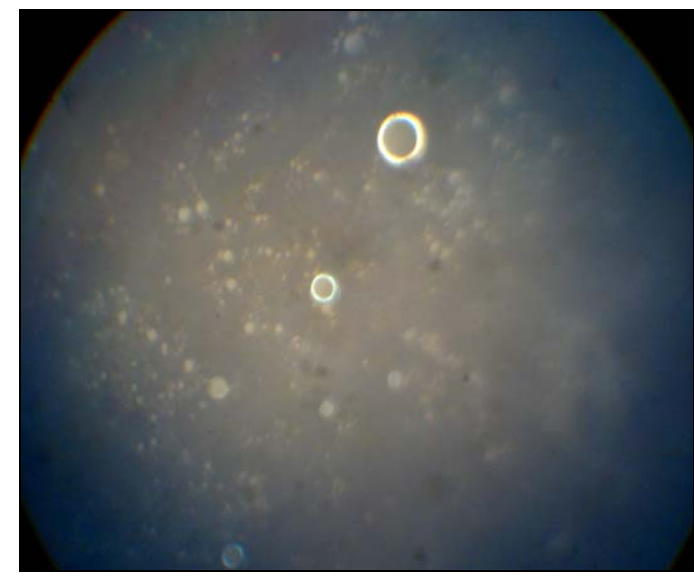

Рис. 2. Суспензія ліпосом (збільшення ×500)

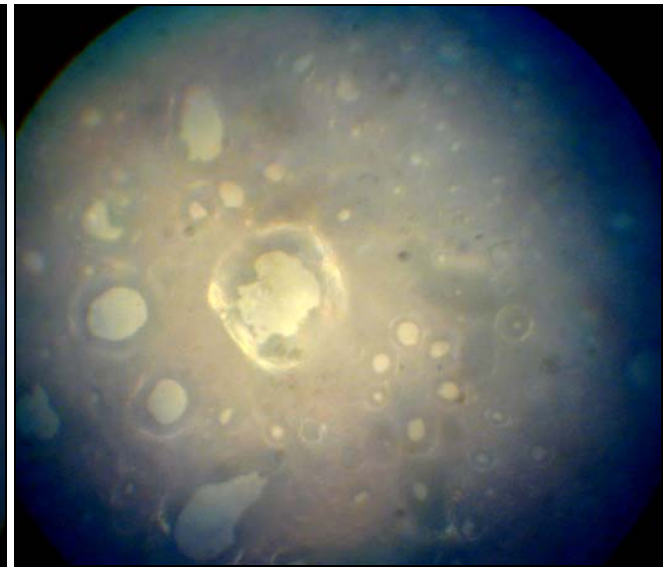

Рис. 3. Ліпосоми з безклітинним гомогенатом лактобактерій (збільшення ×500)

Можна констатувати, що отримання ліпосом із безклітинним гомогенатом лактобактерій дозволяє вирішити проблему визначення ліпосом усередині організму експериментальних тварин, а також безклітинний гомогенат лактобактерій $є$ біологічноактивним компонентом, що зміцнює та стимулює імунну систему організму. 


\section{Висновки}

Достатня кількість методів отримання ліпосом дає можливість цілеспрямовано розробити різні варіанти лікарських засобів на основі ліпосом, що дає можливість зменшити концентрацію лікарської речовини та продовжити термін іiї дії в організмі.

\section{Бібліографічні посилання}

1. Барсуков Л. И. Липосомы // Соросовский образовательный журнал. - 1998. - № 10. - С. $2-9$.

2. Березов Т. Т. Направленный транспорт лекарственных средств с помощью липосом / Т. Т. Березов, Н. В. Яглова, Т. Б. Дмитриева // Вестник РАМН. - 2004. - № 5. - С. $42-47$.

3. Берник О. Р. Природний контейнер з ліками - так спеціалісти називають ліпосоми // Ваше здоров’я. - 1997. - № 11. - С. 5 -7.

4. Гавкалюк М. І. Використання ліпосом у медицині та косметиці / М. І. Гавкалюк, Н. С. Леочко // Діабет і серце. - 2009. - № 10. - С. 123-126.

5. Галицька С. М. Біологічні властивості ліпосом та їх практичне використання / С. М. Галицька, І. С. Нікольський // Фізіол. журн. - 2008. - Т. 54, № 5. - С. 99-105.

6. Корда М. М. Використання ліпосом у клінічній медицині / М. М. Корда, С. В. Бродін, Я. С. Стравський // Ліки. - 1997. - № 5. - С. 67-71.

7. Марголис Л. Б. Липосомы и их взаимодействие с клетками. - М. : Наука, 1986. - 134 с.

8. Матвиенко П. В. Липосомы - «скафандры» для лекарств // Провизор. - 2004. - № 15. - С. $44-48$.

9. Овчинников Ю. А. Биоорганическая химия. - М. : Просвещение. - 1987. - 731 с.

10. Остапченко Л. І. Біологічні мембрани: методи дослідження структури та функцій. - К. : ВПЦ «Київський університет», 2006. - 215 с.

11. Рашке Т. Обзор современных методов инкапсулирования // Косметика и медицина. - 2003. № 2. - C. 44-52.

12. Рыбальченко В. К. Структура и функции мембран. Практикум. - К. : Вища школа, 1988. - 313 с.

13. Чекман І. С. Ліпосомальні форми лікарських засобів: від експерименту до клініки / І. С. Чекман, Л. В. Савченкова, Н. О. Горчакова // Журн. АМН України. - 2006. - Т. 12, № 4. - С. 653-667.

14. Чернусский В. Г. Влияние различных липосомальных форм препаратов на состояние гуморального и клеточного иммунитета у детей, больных бронхиальной астмой // Врач. практика. 2002. - № 1. - С. 96-100.

15. Шальков Ю. Л. Опыт и перспективы использования липосомальной формы противоопухолевых препаратов в клинической онкологии / Ю. Л. Шальков, А. С. Дудниченко, Ю. М. Краснопольский // Клін. хірургія. - 1995. - № 5. - С. 21-23.

16. Шраер Т. И. Применение липосом в раннем лечении экспериментальных ран / Т. И. Шраер, Ю. Г. Шапошников, В. М. Крейнес // Хирургия. - 1994. - № 12. - С. 35-38.

17. Preparation of PEGylated liposomes of docetaxel using supercritical fluid technology / M. Ambikanandan, N. Sachin, P. Deepa, S. Naazneen // The Journal of Supercritical Fluids. - 2010. P. 48-56.

18. Barry B. W. Liposomes and skin: From drug delivery to model membranes / B. W. Barry, G. M. Maghraby, A. C. Williams // European Journal of Pharmaceutical Sciences. - 2008. - Vol. 34, is. 4-5. - P. 203-222.

19. Dorotkiewicz-Jach A. Liposomes as delivery systems for antibiotics / A. Dorotkiewicz-Jach, Z. Drulis-Kawa // International Journal of Pharmaceutics. - 2010. - Vol. 387, is. 1-2. - P. 187-198.

20. Evaluation of cationic liposomes composed of an amino acid-based lipid for neuronal transfection / Y. Obata, G. Ciofani, V. Raffa et al. // Nanomedicine: Nanotechnology, Biology and Medicine. 2010. - Vol. 6, is. 1. - P. 70-77.

21. Spleen plays an important role in the induction of accelerated blood clearance of PEGylated liposomes / T. Ishida, M. Ichihara, X. Y. Wang, H. Kiwada // Journal of Controlled Release. 2006. - Vol. 115, is. 3. - P. 243-250.

Надійшла до редколегіï 15.07.2010 